\title{
Sławomir Wasiński
}

Sławomir Wasiński. Filmoznawca - krytyk filmowy. Absolwent filmoznawstwa na Uniwersytecie Jagiellońskim, gdzie również jest doktorantem. Publikował m.in. na portalach Filmweb. pl, Stopklatka.pl, w Krytycznym Magazynie Internetowym "Verte”, a także w czasopismach: "EKRANy". Specjalizuje się w kinematografii azjatyckiej. Interesuje się także kinem dokumentalnym, fantastyką, sci-fi i horrorem w każdym wydaniu. Jest autorem książek pt. O kinie wartościowym (2010) oraz Buntownik neonowego boga. O kinowej i telewizyjnej twórczości Tsai Ming-lianga (2013). W swojej pracy doktorskiej zajmuje się poetyką kina samurajskiego. 


\title{
Światy mityczne, światy logiczne. Odmienne wizje w twórczości Studia Ghibli
}

\author{
DOI: http://dx.doi.org/10.12775/LC.2014.035
}

bserwując fenomen, jakim jest stale rosnąca popularność anime, nie tylko w Japonii, lecz także na całym świecie, można zadawać sobie pytanie, co leży u źródeł tak dużego sukcesu? Zastanawiając się nad tym problemem, właściwe słowo szybko stanie się odpowiedzią: manga. To właśnie na podstawie mangi corocznie w Japonii powstają setki produkcji animowanych, zarówno seriali, jak i pełnometrażowych animacji. By jednak móc mówić o mandze, w pierwszej kolejności należy określić, czym jest, a także jakie ma znaczenie.

Wyraz złożony z ideogramów man (wykonane szybko i lekko) i ga (rysunek) był używany przez wielu ówczesnych [XIX-wiecznych, dop. S.W.] artystów [...] zanim w XX wieku zaczął oznaczać „komiks”. Definicja, jaką podaje Kōjien, słownik języka japońskiego, brzmi następująco:

Rysunek prosty, humorystyczny i przesadzony.

Karykatura lub satyra społeczna.

Seria obrazków tworzących historię: Comics $^{1}$.

Ze względu na dość skomplikowaną etymologię słowa manga, należy wyjaśnić pewne zawiłości. Przez lata manga przybierała wiele definicji, a jej aktualny status (w Japonii) zależy od pytanego o nią pokolenia. Najstarsi (urodzeni jeszcze przed wojną) twierdzą, że są to karykatury lub satyry w formie krótkiego komiksu zamieszczonego w prasie. Pokolenie powojenne określa mangę jako drzeworyty charakterystyczne dla epoki Edo. Wreszcie współcześni wydawcy i księgarze całkowicie rezygnują z tego słowa na rzecz comics², czyli ogółu mang dostępnych na rynku japońskim. Mimo że w Japonii termin manga wypadł niemal całkowicie z obiegu, na Zachodzie cały czas jest w użyciu. Dzieje się tak m.in. dlatego, by podkreślić odrębność mangi od „Zwyczajnego” komiksu w zachodnim stylu (różniącego się kreską czy perspektywą).

B. Koyama-Richard, Manga. 1000 lat historii, tłum. M. Domagalska, Warszawa 2008, s. 6-7.

2 Zamiast comics w Kraju Kwitnącej Wiśni stosuje się również inną, specjalnie wymyśloną formę, czyli komikku. 


\section{Tokio, ekspozycja w Muzeum Edo, luty 2011 \\ (fot. S. Kołos)}

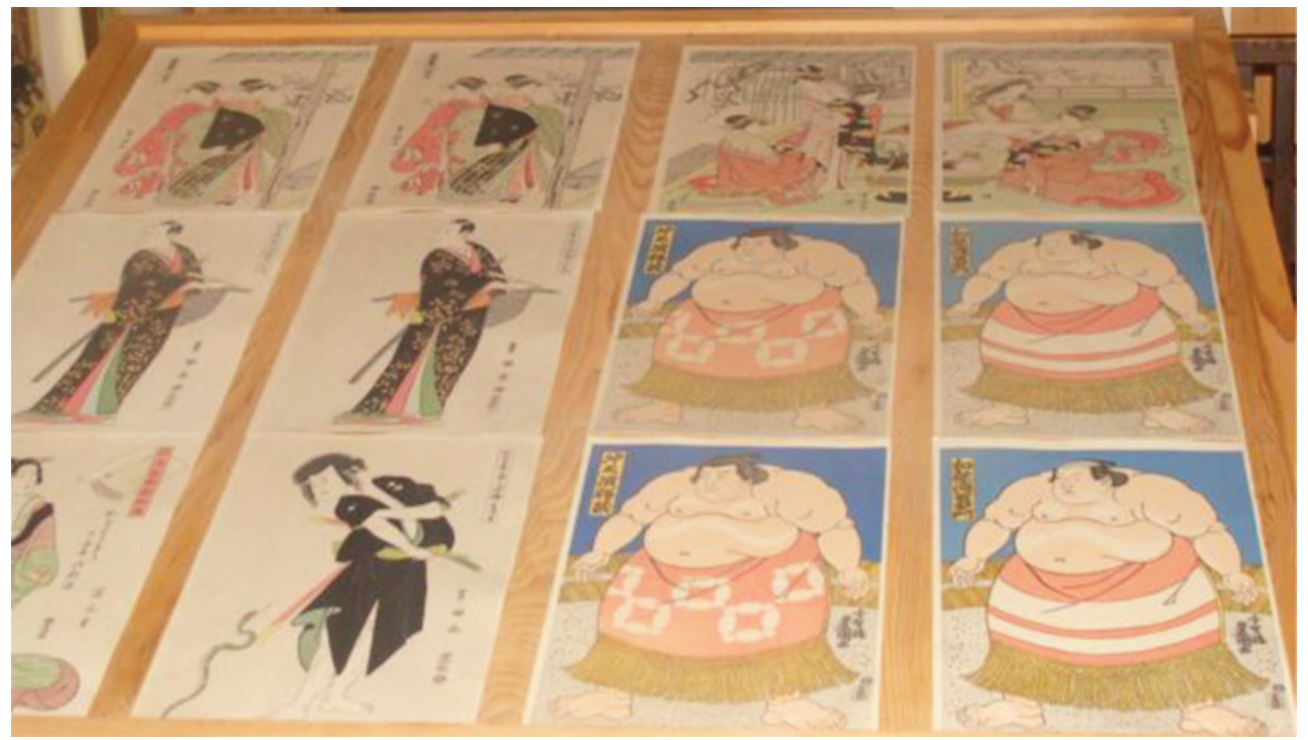

Twórcze dokonania artystów ze Studia Ghibli wymagają odpowiedniego kontekstu. By omawiane w późniejszej części eseju animowane światy nie pozostały w próżni, nakreślę pokrótce rozwój mangi oraz anime, wykazując tym samym ich wzajemne wpływy i relacje.

\section{Manga - krótki rys historyczny}

Zgodnie z definicją słownika Kōjien, manga ma charakter satyryczny oraz karykaturalny. Swoje początki znajduje ona właśnie w karykaturach stworzonych przez budowniczych buddyjskiej świątyni Hōryūji (Świątyni Kwitnącego Prawa). Mocno przerysowane postacie przedstawiają zapewne samych autorów, a datuje się je na koniec VII wieku. Ze względu na swój charakter zostały celowo ukryte pod sufitem świątyni i odnalezione dużo później.

Kolejne kilka wieków upłynęło pokoleniom artystów na doskonaleniu swego warsztatu, koncentrowano się także na wielu tematach, jednym $\mathrm{z}$ nich było dworskie życie. W epoce Heian (794-1185) spod rąk artystów wychodzily przepiękne zwoje, zwane emakimono $^{3}$. Te iluminowane (zdobione barwnymi ilustracjami) zwoje osiągały długość nawet 15 metrów. Ich tematyka była różnorodna: od scen religijnych i historii o upiorach z czeluści buddyjskich piekieł, poprzez portrety ogromnych bitew, na satyrach i życiu codziennym skończywszy. Historie na nich zapisane odczytywało się od prawej do lewej strony. Emaki ilustrowały często krótkie historie, jednak niektóre z tych zachowanych do naszych czasów, potrzebowały wielu pasów papieru. Prócz scen zawierały komentarze lub dopowiedzenia $\mathrm{w}$ formie kaligrafowanego tekstu. Czterem z nich nadano status skarbu narodowego: Ilustrowane zwoje z przekazami o górze Shigi (Shigisan engi emaki); Ilustrowana opowieść o wielkim

${ }^{3}$ Równie często w nazewnictwie stosowano skrót, czyli emaki. Były to zwoje z malowidłami, rozwijane poziomo od prawej do lewej (w opozycji do kakemono - zwojów zarówno z wykaligrafowanym tekstem, jak i np. scenami rodzajowymi, rozwijanymi pionowo od góry do dołu). 
radcy Tomo (Ban dainagon ekotoba); Humorystyczne obrazy zwierząt i ludzi (Chōjū jinbutsu giga) oraz Ilustrowane zwoje do Opowieści o księciu Genjim (Genji monogatari emaki). Szczególnie dwa ostatnie emakimono są niezwykle interesujące. Domniema się, że autorem $\mathrm{Hu}$ morystycznych obrazów zwierząt i ludzi jest Sōjō Toba znany również jako Kakuyū. W tych składających się z czterech zwojów scen, jest widoczna u japońskich artystów głęboka fascynacja antropomorfizmem. Postacie zwierząt wcielających się w najróżniejsze ludzkie zachowania będą częstym motywem opowieści. W przypadku zwojów Toby nadanie ludzkich cech zwierzętom ma głównie charakter satyryczny, prześmiewczy, może stanowić również krytykę społeczną. I tak na pierwszym z nich można zobaczyć walkę sumō, w której żaba zwycięża z zającem, dzięki czemu jej pobratymcy zaśmiewają się do utraty tchu. Inna scena przedstawia małpę odzianą w szaty mnicha, gorliwie recytującą sutrę przed „posągiem Buddy”, który tutaj przyjął postać żaby siedzącej na liściu lotosu. Kolejne emakimono zatytułowane Ilustrowane zwoje do Opowieści o księciu Genjim są interesujące nie tylko ze względu na samą treść, lecz także na historię ich powstania. Opowieść o księciu Genjim to powieść napisana na początku XI wieku przez Shikibu Murasaki, ówczesną damę dworu. Wyjątkowość powieści przejawia się w jej długości i wielowątkowości. Książka liczy 1100 stron i jest podzielona na 54 rozdziały. Tak rozbudowanego dzieła nie było nigdy wcześniej. Już od XII wieku zaczęły pojawiać się iluminowane zwoje przedstawiające kolejne rozdziały przygód księcia. Opowieść jest tak popularna ${ }^{4}$, że doczekała się m.in. w roku 1987 wersji animowanej pt. Genji Monogatari (The Tale of Genji, reż. Gisaburō Sugii). Anime w nieśpieszny sposób ukazuje życie codzienne, dworskie intrygi oraz skomplikowane życie uczuciowe Genjiego.

Isao Takahata, jeden z założycieli Studia Ghibli, w swojej pracy teoretycznej pt. Anime w XII wieku. Elementy XII-wiecznych zwojów malarskich zaklasyfikowanych jako skarb narodowy przypominające filmy i kreskówki (Jüni seiki no animēshon, kokuhō emakimono ni miru eigateki animateki naru mono) wydanej w 1999 roku, wskazuje na podobieństwa mangi i iluminowanych zwojów. Wspomina o tym również Thomas Lamarre:

Animacja jest czasem uznawana za tak starą, jak prehistoryczne malowidła jaskiniowe, ponieważ takie malowidła sugerują sekwencje obrazów. Podobne argumenty zostały przywołane w przypadku kina i komiksów. [...] W przypadku japońskiej animacji nie jest zaskakujące, że niektórzy komentatorzy będą dopatrywali się jej korzeni w ilustrowanych zwojach (emaki) z klasycznej lub wczesnośredniowiecznej Japonii, czyli późnej epoki Heian i wczesnej epoki Kamakura. Koncepcja ta została spopularyzowana i wypromowana przez jednego ze znanych reżyserów Studia Ghibli, Isao Takahatę. [...] Takahata odkrywa zarówno elementy „kinowości” (eigateki) jak i „animacyjności” (animeteki) w średniowiecznych zwojach, głównie w znanych i zabawnych zwierzęcych zwojach, Chōjū jinbutsu giga emakis ${ }^{5}$.

Elementy nazwane przez Isao Takahatę eigateki oraz animeteki jawią się jego zdaniem w iluminowanych zwojach w określony sposób: „(...) emaki, rozwijane stopniowo dla odkrycia każdej sceny, dają wrażenie upływu czasu i rozwoju akcji, podobnie jak mangi, które dzielą historię na części, i oczywiście jak filmy rysunkowe”.

\footnotetext{
${ }^{4}$ O wiecznym życiu tej powieści może świadczyć nieustające zainteresowanie wszelkimi jej kontekstami, które niniejsza strona internetowa próbuje w całości opisać i usystematyzować: http://www.taleofgenji.org/ [stan na dzień: 20.11.2012].

5 T. Lamarre, The Anime Machine. The Media Theory of Animation, Minneapolis 2009, s. 13.

${ }^{6}$ B. Koyama-Richard, op. cit., s. 11.
} 
Rozważania te mogły mieć miejsce tylko i wyłącznie ze względu na kruchą naturę zwojów wymagających staranności w ich przechowywaniu. Były one przeznaczone dla ludzi majętnych oraz mnichów, którzy to pieczołowicie o nie dbali (po powolnym i dokładnym nawleczeniu na drążek obwiązywało się je wstążkami, na całość zakładając futerał). Dzięki temu emakimono przetrwały do naszych czasów. Problemem, który miał zostać rozwiązany dopiero za kilka wieków, był brak alternatywy w postaci kultury i sztuki dla niższych klas społecznych. Wraz z pojawianiem się drzeworytów mniej zamożni (ale szybko się bogacący) mogli uznać je za ich własną, osobistą formę sztuki.

Epoka Edo (1603-1867) przyniosła wiele zmian, zarówno kulturalnych jak i społecznych. Kiedy w 1603 roku Ieyasu Tokugawa otrzymał z rąk cesarza tytuł szoguna, pod jego panowaniem miasto Edo (współczesne Tokio) zaczęło gwałtownie się rozwijać. Społeczeństwo zostało podzielone na cztery klasy: wojowników, chłopów, rzemieślników oraz kupców (odpowiednio shi nō kō shō), jednak podział ten był czysto iluzoryczny. Największa władza należała do wojowników, ale czasy pokoju sprzyjały trwonieniu fortun na rzecz bogacących się mieszczan (rzemieślników i kupców). Tracąc swe majątki daimyo, władcy feudalni, zapożyczali się u kupców. Z czasem lud zyskał możność stworzenia kultury odpowiadającej jego własnym upodobaniom.

Okazja została wykorzystana i na początku XVII wieku artyści zaczęli wytwarzać drzeworyty ukiyoe, co można przetłumaczyć jako „obrazy przepływającego świata”’ (obrazy pokazujące radość z życia; ulotne, przyjemne chwile). Ukiyoe miały niezwykle wiele zastosowań, należy jednak pamiętać, że trafiały w niewysublimowane gusta, a ich głównym zadaniem było sprawienie radości klientom, płacącym za nie bardzo niewygórowane kwoty. Drzeworyty wykorzystywano także czysto praktycznie, jako reklamy sklepów; źródła najnowszych informacji lub „podręczniki” dla dzieci, służące im do nauki i zabawy. Prócz drzeworytów ozdobnych i „użytkowych”, na zlecenie powstawały surimono, ilustracje artystyczne. Charakteryzowały je misterne tłoczenia oraz srebrne i złote zdobienia.

W czasie rządów rodu Tokugawa w Japonii również spopularyzował się druk. Początkowo iluminowane książki posiadały wysokiej klasy zdobienia i równie wysokie ceny, a ich głównymi nabywcami stawali się intelektualiści i najbardziej zamożni. Stan ten zmienił się pod koniec XVII wieku w wyniku działań podjętych przez ród Tokugawa. Położono nacisk na zwiększenie ilości publikacji, przyczyniając się do powstawania nowych wydawnictw, zatrudniano coraz więcej osób odpowiedzialnych za drukowanie i ozdabianie książek. Młode, niedoświadczone wydawnictwa, publikowały różnotematyczne książki, różniące się kolorami okładek:

Jihon donya, niewyspecjalizowane wydawnictwa, publikowały przede wszystkim kusazōshi, książki napisane potocznym stylem, z dużymi ilustracjami. Rozróżnia się kilka typów kusazōshi, w zależności od koloru okładki: „czerwone książki”, akahon, wydawane od roku 1673, skierowane były przede wszystkim do dzieci i zawierały baśnie i legendy; w „czarnych książkach”, kurohon, wydawanych w latach 1744-1751, oraz „zielonych książkach”, aohon, wydawanych od roku 1745, można było znaleźć teksty sztuk teatru kabuki; „żółte książki”, kibyōshi, które pojawiły się około roku 1775 i były bardzo modne aż do roku 1818, zawierały baśnie, opowiadania i powieści. Ostatecznie, na rynku zwyciężyły te ostatnie. Przeznaczone dla masowego odbiorcy dziesięciostronicowe dziełka, o prostym, bogato ilustrowanym tekście, sprzedawane były po

\footnotetext{
7 Por. ibidem, s. 38.
} 
przystępnych cenach. Historia była często prezentowana w odcinkach. Wśród „żółtych książek” wyróżniamy sharebon, „książki bywalców dzielnic rozrywki”, kokkeibon o charakterze komicznym i ninjōbon, opowiadające historie romantyczne i umoralniające. Książka kibyōshi, która odniosła sukces, mogła zostać wydana w nakładzie od tysiąca do dwóch tysięcy egzemplarzy. Osiągnięcie takiego wyniku umożliwiało istnienie licznych bibliotek (kashihonya) ${ }^{8}$.

Powszechność iluminowanych książek, a także długi okres, który minął od rozpoczęcia ich wydawania na szeroką skalę, ukonstytuowały pewne schematy, przyzwyczajając do siebie czytelników. Jednocześnie popychały zdolnych twórców do kreowania nowych zjawisk i terminów. Jednym z nich był Hokusai Katsushika ${ }^{9}$ - znakomity artysta tworzący przede wszystkim drzeworyty, obrazy i albumy. Szeroko znany głównie za sprawą cyklu Trzydzieści sześć widoków na górę Fuji ${ }^{10}$. To właśnie Hokusai jako pierwszy użył sformułowania manga we współczesnym rozumieniu tego słowa. W 1814 roku wydał pierwszy tom Mangi, a jej dokładny tytuł brzmiał Manga Hokusaia do nauki rysowania (Edehon Hokusai manga). Składała się z około 300 prac i była przeznaczona dla chcących doskonalić swoje umiejętności lub posiąść podstawy rysunku. W sumie na zbiór złożyło się piętnaście tomów, będących nieocenioną pomocą dydaktyczną.

Przez następny wiek manga przeżywała swój rozwój w prasie. Kilka lat przed końcem epoki Edo i głębokimi przemianami w strukturach państwowych, w 1862 roku założono pismo „The Japan Punch”. Powołał je do życia angielski malarz Charles Wirgman, który lubował się w tworzeniu karykatur. Wprowadził obcą, zachodnią technikę rysowania, ucząc tym samym Japończyków nowych możliwości i podnosząc ich kunszt artystyczny. Od tego czasu, przez następny wiek, powstawały coraz to nowe czasopisma, dla autorów były one przestrzenią rozwoju umiejętności, natomiast czytelnikom dostarczały wiedzy o najnowszych osiągnięciach świata komiksu. Doświadczenia te pozwoliły kolejnym pokoleniom rysowników na pierwsze próby z animacją, która m.in. za sprawą Amerykanów dotarła do Japonii już na początku XX wieku.

\section{Anime - początki rozwoju}

Termin anime rozumie się poprzez sposób tworzenia filmu animowanego, nie zaś jako gatunek filmowy, odnosi się on tylko i wyłącznie do japońskiej animacji. Niewiele czasu upłynęło, nim Japończycy - zapoznani już z amerykańskimi osiągnięciami - zaczęli tworzyć własne dzieła. Pionierem był Ōten Shimokawa, autor krótkiej animacji pt. Stróż Mukuzo Imokawa (Imokawa Mukuzo Genkanban no Maki) z 1917 roku $^{11}$. W wyniku silnego trzę-

\footnotetext{
8 Ibidem, s. 42-43.

9 Mimo tego, że nazwisko artysty brzmi Katsushika, w literaturze zwykło się go nazywać po imieniu. Można to tłumaczyć faktem, że sam artysta wymyślał sobie wiele pseudonimów, zawierając w nich swoje imię, np. Hokusai szalejący za rysunkami (Gakyōjin Hokusai).

${ }^{10} \mathrm{Na}$ cykl składa się tak naprawdę 46 barwnych drzeworytów. Całość dostępna pod adresem: http:// www.man-pai.com/Grandes_series/Hokusai_Fuji36/hokusai_36_vistas_monte_fuji_e.htm [stan na dzień: 21.11.2012].

11 W Kioto w roku 2005 odnaleziono zaledwie trzysekundową animację, która miała nosić tytuł Ruchomy obraz (Katsudō Shashin). Przypuszcza się, że pochodzi z 1907 r. Jednocześnie uważa się, że została stworzona w celu prywatnych pokazów, dlatego oficjalnie pierwszą animacją pozostaje Stróż Mukuzo Imokawa.
} 
sienia ziemi oraz rozległego pożaru w 1923 roku większa część Tokio została zniszczona, a wraz z nią niemal cały dorobek animatorów i rysowników uległ zniszczeniu bądź zaginął. Okres od drugiej połowy lat 20. XX wieku w japońskiej animacji był czasem odkryć i dążenia do coraz to nowych rozwiązań. Niech za przykład posłużą dwie produkcje, w tamtym czasie pod pewnymi względami przełomowe. Pierwszą z nich jest Czarny kot (Kuroneko Nyago; The Black Cat, 1929), a jej producentem, reżyserem i rysownikiem został Noburō Ōfuji. Animacja, do której specjalnie napisano ścieżkę dźwiękową, opowiada o czarnym kocie i jego bracie, którzy w rytm muzyki tańczą i śpiewają o swoim przodku - tygrysie. Z kolei Yasuji Murata jest uznawany za twórcę pierwszego propagandowego filmu animowanego pt. Podniebny Momotarō (Sora no Momotarō; Momotaro's Sky Adventure) ${ }^{12} \mathrm{z} 1931$ roku. Symbolem Zachodu, który trzeba zwalczyć, staje się tutaj orzeł nękający zwierzęta na wyspie. Na ich prośbę dzielny Momotarō wraz z drużyną wsiada do samolotu bojowego i wyruszają na ratunek mieszkańcom wyspy. W finale dochodzi do konfrontacji z ciemiężycielem, triumfalnego zwycięstwa i wyzwolenia wszystkich zwierząt chcących żyć w pokoju.

Przyglądając się klasycznym japońskim animacjom ${ }^{13}$, niezależnie od tematyki czy stopnia innowacyjności, można dojść do wniosku, że wiele z nich „naznaczonych” jest amerykańskim stylem, którego najjaśniejszym przykładem była twórczość Walta Disneya. Stąd np. duże oczy u bohaterów anime i mang.

Fanem Disneya był sam Osamu Tezuka, zwany przez wielu „ojcem mangi”14. Na taki przydomek pracował już od początku lat 50., kiedy to po znakomicie przyjętej Nowej wyspie skarbów (Shin Takarajima; New Treasure Island, 1947), wydał w Tokio w 1950 roku Cesarza dżungli (Jungle Taitei) znanego szerzej jako Kimba The White Lion. Kilka dekad później pod szyldem Disneya ukazał się Król Lew (The Lion King, 1994) będący oczywistym zapożyczeniem z mangi Tezuki. Kolejnym sukcesem okazał się komiks, którego wydawanie rozpoczęto w 1952 roku; nosił tytuł Atom Żelaznoręki (Tetsuwan Atomu). Na zachodnich rynkach można rozpoznać ten komiks pod tytułem Astro Boy. Najważniejsze jednak dopiero miało się stać. W 1963 roku pojawiła się telewizyjna adaptacja pierwszej serii Astro Boya inicjująca erę japońskich seriali animowanym. Tezuka uruchomił machinę niemożliwą do zatrzymania, w wyniku czego powstawało coraz więcej adaptacji pełnometrażowych lub $\mathrm{w}$ formie seriali.

Na przełomie lat 80. i 90. fala popularności anime zalała również Polskę. Początkowo w TVP1 (wtedy jeszcze obowiązywał skrót TP1) w ramach wieczorynki, emitowany by1, dzisiaj już nieco zapomniany serial pt. Pani Eyżeczka (Supūn Obasan; Mrs. Pepper Pot) ${ }^{15}$ z 1983 roku. Tytułowa bohaterka posiadała zdolność zmniejszania się do rozmiaru łyżeczki. Nieco później, lecz w tym samym paśmie, pojawiła się dobranocka znana i lubiana na całym świecie - Pszczótka Maja (Mitsubachi Māya no Bōken; Maya the Bee, 1975-1976), za którą było odpowiedzialne studio Nippon Animation. W ramówce telewizji Polsat znalazła się Czarodziejka z Księżyca (Bishōjo Senshi Sērā Mūn; Sailor Moon, 1992-1993),

${ }^{12}$ W pracy zbiorowej pt. Studio Ghibli. Miejsce filmu animowanego w japońskiej kulturze tytuł ten przetłumaczono jako Napowietrzny Momotarō.

${ }_{13}$ Znakomita kolekcja japońskich klasycznych animacji obejmująca okres od drugiej połowy lat 20. do lat 50., została wydana przez Digital Meme - instytucję zajmującą się ochroną dziedzictwa narodowego, poprzez restaurowanie kopii klasycznych dzieł filmowych: http://www.digital-meme.com/en/index.html [stan na dzień 21.11.2012].

14 Zwano go także "bogiem mangi" lub "japońskim Waltem Disneyem”.

15 Jednym ze scenarzystów był Mamoru Oshii, twórca m.in. rewolucyjnego Ghost in the Shell (Kökaku kidōtai, 1995). 
która w Polsce została ocenzurowana. Podobnie zresztą jak Dragon Ball (Doragon Bōru, 1986-1989), stworzony na podstawie mangi Akiry Toriyamy. Serial został wprowadzony przez nieistniejącą już stację RTL 7 i zyskał sobie w Polsce tysiące fanów, ale podniosły się również głosy krytyki (związane z epatowaniem przemocą). Największą skarbnicą japońskich seriali animowanych była Polonia 1, w latach 90. stacja wyemitowała ich dwadzieścia trzy. Jeden z nich nosił tytuł Sally Czarodziejka (Mahō-tsukai Sarī; Sally the Witch, 1966-1968), a jego protagonistka zostaje zesłana na Ziemię, by żyć wśród ludzi. Zadanie okazuje się niezwykle trudne, więc Sally jest zmuszona pomagać sobie magią. Jedną z osób biorących udział przy tworzeniu tego anime był Hayao Miyazaki; jest to fakt o tyle ciekawy, że do pewnego stopnia pokazuje, jakie światy w przyszłości będzie on tworzył dla swoich bohaterów.

\section{Studio Ghibli}

W celu zapoznania się z twórczością studia, musimy cofnąć się na osi czasu o kilka lat - do roku 1985. Wtedy to dwóch przyjaciół - Hayao Miyazaki i Isao Takahata - postanowiło założyć własne studio animacji, Studio Ghibli.

Nazwa studia została wymyślona przez Hayao Miyazakiego. Słowo „ghibli”, opisujące gorące wiatry, które wieją na Saharze, było używane jako nazwa włoskiego samolotu zwiadowczego. Jako prawdziwy miłośnik aeronautyki, Miyazaki wiedział o tym, dlatego uznał ten termin za właściwe określenie, mające odzwierciedlić „trąbę powietrzną, jaka utworzy się nad japońską animacją podczas burzy”. Taki dobór słów ukazuje pasję Miyazakiego. Tak na marginesie wspomnę, że słowo „ghibli” tak naprawdę jest wymawiane w języku włoskim jako „ghee-bli”, a nie jak sugeruje zapis fonetyczny nazwy studia w katakanie - „jiburi”, ale teraz jest już zbyt późno, by naprawić ten błąd, gdyż sława umocniła złą wymowę ${ }^{16}$.

Od początku istnienia studia tworzono w nim dzieła charakteryzujące się perfekcjonizmem, ogromnym zróżnicowaniem tematycznym oraz wyraźnie wyczuwalnym zaangażowaniem artystów w swoją pracę. Po analizie wszystkich produkcji, jakie wyszły pod szyldem Studia Ghibli, można wysnuć wniosek, że jego dzieła są oparte na opozycjach. W węższym kontekście, zwróciła na to uwagę także Katarzyna Kulpińska, opisując Podniebna pocztę Kiki (Majo no Takkyūbin; Kiki's Delivery Service, 1989): „[...] dom - obca okolica, prowincja duże miasto, potrzeba niezależności - potrzeba bliskości i akceptacji, kontemplacyjna cisza - zgiełk miasta, świat Zachodu - świat Wschodu"17. Jednak najważniejsze przeciwieństwa nie występują w warstwie wewnątrztekstowej, którą rozumiem tutaj jako całość twórczości Studia Ghibli, są jedynie konsekwencjami opozycji ważniejszej, realnej - opozycji między artystycznymi wizjami Hayao Miyazakiego i Isao Takahaty. Jawi się ona przede wszystkim w odrębnych wizjach świata obu artystów.

16 Yoshimasa Mizuo, Ukryta gwiazda Studia Ghibli: Producent Toshio Suzuki [w:] J. Zaremba-Penk, M. Lisiecki (red.), Studio Ghibli. Miejsce filmu animowanego w japońskiej kulturze, tłum. J. Zaremba-Penk, Toruń 2012, s. 32.

${ }_{17}$ K. Kulpińska, Podniebna poczta Kiki Hayao Miyazakiego jako autorska koncepcja rite de passage [w:] J. Zaremba-Penk, M. Lisiecki, red., op. cit., s. 118. 


\section{Hayao Miyazaki - niepohamowana fantazja}

Wspominana już wyżej Sally Czarodziejka była jedną z pierwszych produkcji, która nakierowała Miyazakiego w stronę fantastycznych światów. Jednym z głównych tematów przewijających się przez jego twórczość jest ekologia, problem ingerencji człowieka w naturę i jego szeroko pojęte konsekwencje. Zanim Studio Ghibli powstało, w 1978 roku Hayao Miyazaki wyreżyserował serial składający się z dwudziestu sześciu odcinków pt. Conan, chłopiec z przyszłości (Mirai Shōnen Konan; Future Boy Conan). Przenosi on nas w postapokaliptyczny świat, w którym po III wojnie światowej ludzkość niemal wymarła. Większość dotychczas znanych lądów znalazła się pod wodą, nie licząc kilku wysp. Jedenastoletni chłopiec imieniem Conan ocalał wraz z dziadkiem, ale ich kłopoty zaczną się z chwilą, kiedy znajdą na plaży Lanę - dziewczynkę w wieku Conana - uciekinierkę z wyspy nazywanej Industrią. Walka rozegra się między ludźmi zafascynowanymi najnowszymi technologiami a tymi stojącymi po stronie natury. Dlatego nie może dziwić widok, kiedy to podczas dziecięcych zabaw, na pokrytej zielenią wyspie, nagle napotyka się niedziałające roboty lub różnego rodzaju ciężkie maszyny bojowe.

Inspiracją dla pierwszej animacji Hayao Miyazakiego była manga jego autorstwa, którą rozpoczął wydawać w 1982 roku (a zakończył w 1994!), natomiast dwa lata później, w 1984 roku powstało anime zatytułowane Nausicaä z Doliny Wiatru (Kaze no Tani no Naushika; Nausicaä of the Valley of the Wind). Uznaje się je za pierwszą produkcję Studia Ghibli, chociaż zostało ono założone rok później, m.in. dzięki sukcesowi filmu Miyazakiego. Nausicaä $z$ Doliny Wiatru kontynuuje temat konfliktu na linii człowiek kontra natura, ale tym razem jego wymowa jest o wiele poważniejsza. Autor stworzył tutaj jeden z mroczniejszych i bardziej złożonych światów. Oto czarna wizja przyszłości: cywilizacja na skutek permanentnego i błyskawicznego rozwoju przemysłowego zawłaszcza sobie coraz większe połacie Ziemi. Konsekwencją tego stają się: jej wyjałowienie i wszechobecne trujące gazy wypuszczane do atmosfery. Wreszcie dochodzi do wojny zwanej Siedmioma Dniami Ognia, wraz z którą zostaje utracony cały dotychczasowy postęp technologiczny. Przez następne tysiąclecia większość ludzi wyginęła, ci którzy przetrwali w niewielkich enklawach, muszą zmagać się z toksycznym lasem Fukai, porastającym niemal całą planetę. Rosną w nim ogromne grzyby wydzielające trujące gazy, a ewolucja na skażonej Ziemi powołała do życia gigantyczne larwy zwane Ohmu (jap. O-mushi). Kiedy wędrują, niszczą wszystko na swej drodze. Tak przygotowany grunt zostaje zagarnięty przez las, dla ludzi zostaje coraz mniej miejsca. Nie to jest jednak najbardziej przerażające. Największą grozę budzi reakcja ludzi w tak krytycznej sytuacji. Nie jednoczą się, nie próbują sobie pomagać, zamiast tego prowadzą wojny o ostatnie skrawki bezpiecznej ziemi. Choć zakończenie nieco łagodzi wydźwięk filmu, jego treść jednoznacznie wskazuje na konsekwencje działań człowieka.

Krótkometrażowy teledysk do piosenki duetu Chage \& Aska z połowy lat 90., noszący tytuł On Your Mark (On Yua Māku), był eksperymentem z animacją cyfrową. Miejscem historii po raz kolejny jest świat po zagładzie nuklearnej, a o zagrożeniu promieniowaniem informują widza pojawiające się kilka razy znaki ostrzegawcze. Miasta zamknięte są pod kopułami, a nadzór policji jest nieprzerwany. Po akcji mającej na celu rozbicie tajemniczej 
sekty, dwaj policjanci natrafiają na uwięzioną dziewczynę ze skrzydłami anioła. Achronologiczność w warstwie fabularnej determinuje jej wariacyjność, ukazując tym samym kilka możliwych scenariuszy. Pomimo tragicznej wizji przyszłości, jaka jawi się w obrazie, kontrastujące $\mathrm{z}$ nim słowa piosenki oraz odrobina nadziei w postaci zachowania policjantów (za wszelką cenę chcą pomóc dziewczynie w ucieczce, co im się w końcu udaje), zostawiają widza $\mathrm{z}$ wiarą $\mathrm{w}$ możliwą zmianę postępowania człowieka wobec natury. Trudno również nie zwrócić uwagi na fakt, że uskrzydlona dziewczyna jest niezwykle podobna do bohaterki pierwszego filmu Miyazakiego - Nausicai, co skłania do snucia odważnych interpretacji.

Świat fantazji stworzony na potrzeby Księżniczki Mononoke (Mononoke-hime; Princess Mononoke, 1997) jest bez wątpienia jednym z największych i najbardziej złożonych (porównywalnym tylko ze Spirited Away: W krainie Bogów, o którym będę pisał w dalszej części artykułu, oraz wspominanej już Nausicai z Doliny Wiatru). Wypełniają go odwołania do japońskiej tradycji, mitologii i wierzeń religijnych. Wizualnym przejawem tych ostatnich są duchy mononoke właściwe dla shintoizmu. Ich ukazywanie się np. w lasach, dowodzi nieprzerwanego biegu życia roślin, braku ingerencji w naturę. Tym razem akcja dzieje się w przeszłości (epoka Muromachi, 1336-1573), w czasach, kiedy bogowie żyli na Ziemi. Młody wojownik Ashitaka wyrusza na spotkanie z Shishi-gami, bogiem zwierząt, gdyż tylko ten może zdjąć z niego śmiertelną klątwę. Po drodze spotka dwie kobiety, dwie strony konfliktu. Tytułową księżniczkę Mononoke, która naprawdę ma na imię San i została wychowana przez wilki oraz panią Eboshi - zarządczynię Żelaznego Miasta. San z pogardą spogląda na wszystkich ludzi i wraz z wilkami i innymi zwierzętami walczy przeciwko Eboshi, ponieważ ta ostatnia w celu ciągłego rozwoju miasta, wyrobu broni i żelaza, karczuje ogromne połacie lasów, nie zważając na duchy i zwierzęta, które je zamieszkują. Ashitaka musi opowiedzieć się po którejś ze stron. Miyazaki stworzył świat, w którym natura broni się całą swą mocą. Inteligentne zwierzęta jednoczą się, by walczyć z ludźmi nawet za cenę życia. Najistotniejsze jednak jest zakończenie historii, jego wydźwięk, o wiele bardziej pesymistyczny niż nastąpiło to w Nausicai z Doliny Wiatru: cóż z tego, że otacza nas ogromne bogactwo naszej planety, skoro wszystko zostaje zaprzepaszczone poprzez nieustające konflikty.

Gdzie szukać źródeł wciąż powracającego motywu natury skonfrontowanej z człowiekiem? W latach 70. Hayao Miyazakiego trafil na jedną z książek Sasuke Nakao - botanika podróżującego m.in. po Bhutanie. Na podstawie licznych wyjazdów Nakao doszedł do interesujących wniosków. Nie tylko uznal, że rośliny, które dojrzewają w podobnych strefach klimatycznych są do siebie zbliżone, ale odkrył także zbieżność ludzkich kultur i obyczajów kształtowanych przez niemal identyczne rodzaje roślinności w swoich (odrębnych przecież) środowiskach. Miyazaki potrzebował w tamtym czasie poglądu pozwalającego zrozumieć mu świat na nowo. Wynikało to z utraty pewnych wartości i silnej potrzeby przewartościowania swoich wizji, co tłumaczy poniższy cytat:

Poczucie winy związane z wojną od dawna prześladuje Miyazakiego, który urodził się w 1941 roku - Pearl Harbor - i leży u źródeł wielu motywów znanych z twórczości mistrza animacji. Jego rodzina posiadała fabrykę produkującą części do myśliwców Zero. Czerpała profity z wojny, jednocześnie nie ponosząc żadnej z ofiar, jakie za szaleństwo militarystów przyszło zapłacić japońskiemu społeczeństwu. [...] Wojenne i powojenne cierpienie, którego świadkiem był młody Miyazaki [...] sprawiło, że zwątpił w swoje pochodzenie i wartość rodziny ${ }^{18}$.

\footnotetext{
18 M. R. Wiśniewski, Fantastyczne światy Hayao Miyazakiego, „Nowa Fantastyka” 2008, nr 8 (311), s. 11.
} 
Niekompletność rodziny to kolejny leitmotiv treściowy przejawiający się w animacjach Miyazakiego. Rodzice często bywają nieobecni, np. z powodu choroby (Mój sąsiad Totoro), przymusowej rozłąki z nimi (Podniebna poczta Kiki), czy też klątwy (Spirited Away: W krainie Bogów). Młode bohaterki (głównymi postaciami niemal wszystkich produkcji tego reżysera są małe dziewczynki lub młode kobiety - inspirowane matką

Miyazakiego, kobietą inteligentną i nowoczesną) zawsze muszą radzić sobie bez pomocy najbliższych. Chociaż mogą liczyć na wiele życzliwych postaci napotkanych podczas swoich przygód, najtrudniejsze wyzwanie, jakim jest wkroczenie w dorosłość, muszą wykonać samodzielnie.

To, że Hayao Miyazaki jest pacyfistą, nie powinno zaskoczyć nikogo (szczególnie w wyżej wspomnianym kontekście). Następnym wielkim tematem reżysera jest wojna, sprzeciwia się jej ukazując jej bezsensowność. Szczególnie dobrze widać to na podstawie $R u$ chomego zamku Hauru (Hauru no Ugoku Shiro; Howl's Moving Castle) z 2004 roku. Jest to opowieść o osiemnastoletniej Sophie, która pod wpływem klątwy zamienia się w staruszkę. By odzyskać swoją dawną formę szuka, pomocy u czarodzieja imieniem Hauru. Kluczem do zagadki okażą się relacje Hauru z Calcifer - duchem ognia napędzającym zamek młodego czarodzieja. Tłem dla tych wydarzeń jest tajemnicza wojna, w której obok regularnej armii ścierają się ze sobą magia i demony. Bezcelowość bratobójczej walki u progu zagłady staje się czynnikiem zawsze ignorowanym, sytuacja ta powtarzała się stale, niezależnie od świata przyszłości czy przeszłości. Miyazaki mówi więc wyraźnie, że historia nie jest w stanie nauczyć niczego ludzi, zawsze mogących wywołać poważny konflikt, nawet w obliczu największego zagrożenia.

W 1986 roku świat ujrzał anime pt. Laputa - podniebny zamek (Tenkū no Shiro Rapyuta; Laputa: Castle in the Sky) ${ }^{19}$. Historia rozpoczyna się tajemniczo. Dwójka sierot poznaje się w nietypowych okolicznościach. Dziewczynka imieniem Sheeta postanawia za wszelką cenę bronić jedynej pamiątki po swojej matce (turkusowy kamień), dlatego decyduje się na skok z wnętrza sterowca należącego do organizacji rządowej, pragnącej przechwycić kamień. To właśnie on ratuje Sheetę przed śmiertelnym upadkiem. Całe zdarzenie widzi Pazu, chłopiec pracujący w wiosce, który postanawia jej pomóc. Miyazaki, tworząc początkowe miejsce przygód swoich bohaterów, inspirował się walijskim miastem górniczym. Jego architektoniczną złożoność oraz dokładność w oddawaniu detali misternych konstrukcji, możemy w pełni podziwiać w trakcie scen, kiedy to podniebni piraci ścigają na swoich latających maszynach Pazu i Sheetę. To właśnie w Lapucie Miyazaki po raz pierwszy, i z całą mocą, odkrywa przed widzami swą wielką fascynację, jaką jest latanie.

Podobny pomysł w związku z przedstawieniem świata, przyszedł japońskiemu twórcy podczas prac nad Podniebna pocztą Kiki (Majo no Takkyūbin; Kiki’s Delivery Service, 1989). Opowieść jest prosta. Oto Kiki - trzynastoletnia czarownica, której tradycja każe opuścić rodzinny dom i zamieszkać w nieznanym mieście, nie posiadającym wśród swoich mieszkańców innej czarownicy. Wraz ze swoim kotem, wsiadają na miotłę i wylatują w nieznane. Pod względem struktury świata, to co najbardziej istotne, to owe nieznane miasto, do którego trafia młoda czarownica. Hayao Miyazaki odbywał często podróże po Europie, w ich trakcie robił notatki i zdjęcia, kręcił różne obiekty, słowem - chłonął architekturę miast. Jak zwykle w jego animacjach świat jest fikcyjny, tym razem jednak „miasto-świat” składa się

\footnotetext{
${ }_{19}$ W Polsce znane jest również tłumaczenie Laputa-zamek w chmurach.
} 
z najciekawszych elementów różnych miast odwiedzonych przez reżysera. Należy dodać, że głównym wzorcem był dla niego Sztokholm. Plan miasta najlepiej podziwiać z lotu ptaka, podczas powietrznych podróży Kiki.

Kolejnym filmem wykorzystującym powietrzne maszyny, a także dobrym przykładem relacji obiektywnej rzeczywistości i fantastyki stał się Szkarłatny pilot (Kurenai no Buta; Porco Rosso, 1992). W okresie międzywojennym poznajemy Porco Rosso, asa przestworzy podczas I wojny światowej, obecnie łowcę głów do wynajęcia. Ściga powietrznych piratów i stara się udaremniać ich napady na bezbronne aeroplany. Taki stan rzeczy mógłby trwać nadal, gdyby nie pewien fakt. Gdy po jednej z akcji podczas wojny, Porco wrócił jako jedyny ocalały ze swego oddziału, spadła na niego klątwa, zamieniając go w świnię. Miejscem akcji są wyspy Adriatyku, jedną z nich (blisko chorwackiego wybrzeża) zamieszkuje Porco Rosso. Miyazaki stara się oddać pieczołowicie wizję, atmosferę tamtych czasów. Elementy fantastyczne dominują jednak nad całą materią świata przedstawionego. Wartością naddaną w kontekście rozważań nad strukturą świata staje się wyalienowanie bohatera. Ze względu na swój wygląd, musi zmagać się z dodatkowymi przeciwnościami losu.

Po pierwszym europejskim pokazie Spirited Away: W krainie Bogów, który odbył się w grudniu 2001 roku w Paryżu przy okazji festiwalu animacji zwanego Nouvelles images du Japon, Hayao Miyazaki podczas konferencji prasowej wypowiedział się m.in. na temat fantazji i logiki.

Wierzę, że fantastyka rozumiana jako wyobraźnia jest bardzo ważna. Nie powinniśmy się trzymać zbyt blisko codziennej rzeczywistości, ale dać miejsce rzeczywistości serca, umysłu i wyobraźni. Te rzeczy mogą nam w życiu pomóc. [...] Musimy być otwarci na siłę wyobraźni, która wprowadza coś pożytecznego do rzeczywistości. [...] Logika używa przedniej części mózgu, to wszystko. Ale nie możesz zrobić filmu z logiką. Albo, jeśli spojrzeć na to inaczej, każdy może zrobić film używając logiki. Ale mój sposób polega na nie używaniu logiki. Próbuję kopać gębiej $\mathrm{w}$ studni mojej podświadomości. W odpowiednim momencie tego procesu, pokrywa otwiera się i zostają wyzwolone bardzo różne pomysły i wizje. $\mathrm{Z}$ nimi mogę zacząć tworzyć film. Ale może to lepiej, że nie otwiera się tej pokrywy do końca, ponieważ jeśli uwolnisz swoją podświadomość, może to skomplikować życie towarzyskie oraz rodzinne. [...] Są głębsze rzeczy niż prosta logika, które prowadzą do stworzenia historii ${ }^{20}$.

Nietrudno zaryzykować stwierdzenie, że w wypadku właśnie Spirited Away: W krainie Bogów (Sen to Chihiro no Kamikakushi; Spirited Away, 2001), za który Hayao Miyazaki otrzymał Oscara, pokrywa jego podświadomości otwarła się najszerzej, co zaowocowało najbardziej fantastycznym ze światów w dotychczasowej karierze Japończyka. Wszystko zaczyna się od przeprowadzki dziesięcioletniej Chihiro i jej rodziny. Po drodze do nowego domu gubią się, postanawiają zatrzymać samochód i rozejrzeć się po okolicy. Dziewczyna i jej rodzice niespodziewanie trafiają w miejsce kojarzące się z wesołym miasteczkiem, jest ono jednak opuszczone. Rodzice skuszeni zapachem smakowitych potraw zaczynają jeść, a karą za to jest przemiana w świnie. Okazuje się, że Chihiro trafiła do tytułowej krainy bogów i aby odzyskać rodziców, będzie musiała tam pracować. Reżyser umieszcza małą Chihiro w łaźni dla bogów. Galeria barwnych (i brudnych) bóstw daje możliwość nawiązań do

${ }^{20}$ Zapis konferencji prasowej pod adresem: http://www.midnighteye.com/interviews/hayao-miyazaki/ [stan na dzień: 02.12.2012]. Za redakcję tekstu odpowiada Tom Mes. 
japońskiej mitologii i wierzeń. W tym hermetycznym świecie współpraca ludzi i zwierząt (obdarzonych ludzkimi przymiotami) to widok powszedni, a bogowie stąpający między istotami śmiertelnymi traktowani są jak kolejni klienci do wyszorowania. Spirited Away, dzięki ogromowi i złożoności świata oraz mnogości postaci, stał się wielkim artystycznym osiągnięciem Hayao Miyazakiego.

Głównymi bohaterkami animacji zatytułowanej Mój sąsiad Totoro (Tonari no Totoro; My Neighbor Totoro, 1988) są siostry: Satsuki i Mei. Wraz z ojcem przeprowadzają się na wieś, do starego domu, by być bliżej chorej matki przebywającej w szpitalu. Już na samym początku odkrywają w swoim domu susuwatari, duszki wyglądem przypominające kulki sadzy. Niedługo potem mała Mei wpada na trop leśnych duchów, które nazywa „Totoro”21. Dzieło to charakteryzuje spojrzenie z perspektywy dziecka. Tylko ono ma dostęp do fantastycznego świata ukrytego w pniu ogromnego drzewa. Żaden dorosły nie jest w stanie dostrzec przyjaznych duszków domu ani tym bardziej wielkiego, pokrytego futrem trolla. Miyazaki rozsiewa fantastyczne elementy w realnym świecie, które powoli, lecz sukcesywnie kiełkują, przykrywając rzeczywistość baśniowymi liśćmi.

Ponyo (Gake no Ue no Ponyo; Ponyo on the Cliff by the Sea) z 2008 roku jest pod pewnymi względami animacją wyjątkową. Pewnego dnia Sosuke - pięcioletni chłopiec mieszkający wraz z mamą nad morzem - znajduje blisko brzegu złotą rybkę. Postanawia się nią zaopiekować i nadaje jej imię Ponyo. W tym samym czasie Fujimoto - mag żyjący w głębinach oceanu, przemierzający je swą łodzią podwodną - dostrzega zniknięcie jednej ze swoich córek. Szybko orientuje się gdzie jest, równocześnie próbując sprawić, by wróciła do domu. Świat rzeczywisty, czyli nadmorskie miasteczko, oraz świat wyobraźni, zapełniony feerią barw, reprezentowany tutaj przez niekończący się ocean, zaczynają się przenikać. W większości filmów Miyazakiego obecny był jeden lub drugi, rzadko oba jednocześnie. Im dłużej Ponyo, pragnąca zostać dziewczynką, przebywa na lądzie, tym bardziej wzburzony jest ocean. Wreszcie zatapia miasteczko, dając tym samym dominację czystej wyobraźni. W tym świecie nawet dorośli (w opozycji do Mojego sąsiada Totoro) widzą magię. Wyjątkowość tej produkcji jawi się w jeszcze jednym aspekcie. $W$ wielu historiach postacie powracają do rzeczywistości (vide Spirited Away: $W$ krainie Bogów), tutaj ich przygoda będzie trwała nadal, ponieważ Ponyo spełnia swoje marzenie i zostaje z Sosuke. W końcu nie od dziś wiadomo, że czasami fantazja nigdy się nie kończy.

\section{Isao Takahata - chodząca logika}

Chodząca logika - taki właśnie przydomek Isao Takahata otrzymał od swoich najbliższych współpracowników ${ }^{22}$. Głównie za sprawą charakteru swoich animacji, zarówno w postaci licznych serii, jak i kilku pełnych metraży. W niemal wszystkich jego produkcjach świat jest realistyczny, rządzi się żelaznymi prawami logiki, dzięki czemu znajduje się w nim miejsce na naturalizm i często obecną „magię codzienności”.

${ }^{21}$ Dziewczynka ma na myśli trolla, jednak przekręca słowa. Zamiast poprawnego „Torōru", wymawia je „Totoro".

22 Por. http://www.nausicaa.net/miyazaki/interviews/oshii_on_mt.html [stan na dzień: 04.12.2012]. Mamoru Oshii opowiada o znajomości z Miyazakim i Takahatą. Wywiad przeprowadziła Rika Ishii. 
Jego debiutancki film pełnometrażowy z 1968 roku zatytułowany Książę Stońca: Wielka przygoda Horusa (Taiyō no Ōji: Horusu no Daibōken; Horus: Prince of the Sun) stanowi dzieło zupełnie odrębne, będące zaprzeczeniem późniejszych dokonań Takahaty. Historia dzieje się w pokrytej śniegiem oraz skutej lodem Skandynawii w epoce żelaza. Tuż przed śmiercią ojciec Horusa wyjawia chłopcu tajemnicę ich pochodzenia. Okazuje się, że zamieszkiwali jedną z wiosek nękanych przez Grunwalda, a ostatnią wolą ojca jest, by Horus pokonał potężnego czarownika. Nakreślony tutaj świat spełnia większość założeń z gatunku heroic fantasy. Reżyser wyraźnie oddziela dobro od zła, a za bohatera obiera sobie niepozornego chłopca, który otrzyma zadanie na pozór przerastające jego siły. W czasie wędrówek po mroźnej krainie Horus nauczy się nie tylko stawiać czoło niebezpieczeństwu, lecz także wykształci w sobie istotne ludzkie wartości, za pomocą których zyska szansę ostatecznego zwycięstwa.

Podczas swojej dalszej kariery (jeszcze przed otwarciem Studia Ghibli) Isao Takahata skupił się prawie całkowicie na tworzeniu serii filmowych. W roku 1974 w japońskiej telewizji Fuji TV przez cały rok emitowano serial dla najmłodszych Heidi, dziewczyna Alp (Arupusu no Shōjo Haiji; Heidi, Girl of the Alps). Powstał na podstawie klasycznej powieści szwedzkiej pisarki Johanny Spyri opowiadającej o pięcioletniej dziewczynce, która straciła rodziców. Ciotka zawozi Heidi do domu dziadka w Alpach, gdzie dziewczyna zaskarbia sobie sympatię jego i osób z najbliższego otoczenia. Pięć lat później, w 1979 roku, ta sama telewizja w kolejnym rocznym cyklu wyemitowała Anię z Zielonego Wzgórza (Akage no An; Anne of Green Gables). Podobnie jak duża część dorobku Takahaty, była to adaptacja klasycznego dzieła. Autorką oryginalnej powieści była pisarka kanadyjskiego pochodzenia - Lucy Maud Montgomery. Istotny jest fakt, że japoński reżyser zawsze starał się być wierny oryginalnej historii, nie inaczej było w tym wypadku. Tytułowa Ania jest sierotą, która w wyniku pomyłki zostaje wysłana do domu rodzeństwa Cuthbertów. Kiedy Maryla i Mateusz przyjmą ją do rodziny, dziewczyna obdarzona żywiołowym charakterem nie pozwoli im się nudzić (ani utrzymać spokojnego charakteru domu na Zielonym Wzgórzu). W obu przypadkach Takahata posługuje się prostymi środkami, pokazuje sceny zabaw z przyjaciółmi, również proces przekonywania do siebie obcego środowiska, w którym znalazły się dziewczynki. Jedną z największych wartości obu tych światów jest przyjaźń, możliwa do zawarcia w nawet najbardziej nieoczekiwanych okolicznościach.

Od początku lat 80 . kolejne dzieła Takahaty pozostają osadzone w realnych światach. Już w 1981 roku powstaje Chie Rozrabiaka (Jarinko Chie; Chie the Brat), w którym to filmie dziesięcioletnia Chie, niezwykle rezolutna dziewczyna, prowadzi rodzinny biznes (bar), podczas gdy jej rodzice żyją w separacji. Mimo że przed dziewczyną piętrzą się kłopoty, podchodzi do życia pogodnie. Osobne spotkania z rodzicami powinny być dość smutnym przeżyciem, tymczasem Takahata wykorzystuje je, by wywołać uśmiech na twarzy głównej bohaterki i widzów. Przykład takiej sytuacji stanowi scena, w której dziewczyna spotyka się z matką, a cała wycieczka kończy się w kinie. Razem oglądają Godzillę z synem, malec uczy się ziać radioaktywnym oddechem (wciąż niebieskim, czyli jeszcze o najsłabszej mocy rażenia). Anime odniosło tak duży sukces, że jeszcze w tym samym roku reżyser stworzył jego serial pod tym samym tytułem. Jego emisja trwała do końca marca 1983 roku.

Gauche Wiolonczelista (Sero Hiki no Gōshu; Gauche the Cellist, 1982) to krótka historia o tytułowym wiolonczeliście zamieszkującym małe miasteczko. Mężczyzna szuka inspiracji dla swojej twórczości, która z jakiegoś powodu przestała się rozwijać. Bohatera, kontem- 
plującego w niewielkiej chatce, zaczynają odwiedzać zwierzęta, każdej nocy inne. Pod ich wpływem Gauche odnajduje nowe inspiracje. Antropomorfizacja (zwierzęta proszą wiolonczelistę o zagranie konkretnych utworów) staje się dowodem fascynacji reżysera tym tematem i pewną zapowiedzią powrotu do tematu, co Takahata uczyni w jednym z kolejnych filmów. Najistotniejsza jednak jest próba ukazania niemocy twórczej, którą w świecie Takahaty (podobnie jak w życiu) można przezwyciężyć, wsłuchując się w naturę, starając się wyciszyć i po prostu słuchać.

Następny film potwierdza, że Isao Takahata nie bez przyczyny został nazwany „chodzącą logiką". Mam na myśli pierwszy film reżysera, powstały po założeniu Studia Ghibli, czyli Opowieść o kanałach $w$ Yanagawa (Yanagawa Horiwari Monogatari; The Story of Yanagawa's Canals, 1987). Był to niemal trzygodzinny dokument portretujący piękno miasta, ukazujący turystów w donkobune - łodziach używanych w Yanagawa - oraz proces renowacji kanałów. Początkowo miała to być animowana historia na fali popularności Nausicai z Doliny Wiatru, jej swoista kontynuacja. Gdy Takahata zjawił się na miejscu, historia miasta oraz mieszkańców starających się o zachowanie kanałów w dobrym stanie mocno go zainteresowała. Chęć przedstawienia prawdziwego świata oraz „bohaterów” z krwi i kości zwyciężyła. Miyazaki wsparł w tym pomyśle Takahatę, finansując przedsięwzięcie z własnych pieniędzy. Jednym z najważniejszych filmów Studia Ghibli bez wątpienia jest Grobowiec świetlików (Hotaru no Haka; Grave of the Fireflies) z 1988 roku. Akiyuki Nosaka stworzył autobiograficzną powieść, na podstawie której Isao Takahata napisał scenariusz do swojego dzieła. Opowieść przenosi nas do brutalnych realiów II wojny światowej. Na kilka miesięcy przed jej końcem czternastoletni Seita i jego czteroletnia siostrzyczka Setsuko zostają sierotami. Po śmierci matki, rodzeństwo przemierza bombardowane z powietrza Kobe w poszukiwaniu schronienia i pożywienia. Trafiają do ciotki, która jednak szybko zaczyna uważać ich za balast. Seita postanawia wynieść się z jej domu i poszukać wraz z siostrą szczęścia gdzie indziej. Od tej pory rodzeństwo zdane jest wyłącznie na siebie, a sytuacja pogarsza się z dnia na dzień. Realizm świata przedstawionego jest porażający, może o tym świadczyć sposób rozpoczęcia historii. Scena ukazuje śmierć głodową Seity, by po chwili przenieść widza we wcześniejsze stadium opowieści. Charakter świata zostaje określony od samego początku, wydarzenia nie potoczą się dobrze, a wojna - wszechobecna i niszczycielska - zabierze wszystko.

Jeśli któraś z animacji Takahaty zasługuje na miano naturalistycznej, to jest nią Powrót do marzeń (Omohide Poro Poro; Only Yesterday, 1991) ${ }^{23}$. Lubiąca wspomnienia Taeko jest dwudziestosiedmioletnią urzędniczką w Tokio. Codzienna praca w mieście nie sprawia jej satysfakcji, podobnie jak życie osobiste. Postanawia wyjechać na wieś do bliskich. Już w pociągu zaczynają jej się przypominać czasy dzieciństwa, Taeko sięga pamięcią do coraz to nowych zdarzeń, nie zawsze dla niej przyjemnych. Kiedy dociera na miejsce, strumień pamięci nie przestaje płynąć, a zastanawianie się nad swoją przeszłością doprowadzi do wykrystalizowania przyszłości. Zgiełk ogromnej metropolii kontrastuje tu z sielskim i spokojnym krajobrazem wsi. Wspomniany naturalizm objawia się za sprawą ukazywania scen z życia codziennego: rozmów o sposobach uprawy roli; scen zbiorów krokosza barwierskiego (kwiatów wykorzystywanych później jako barwnik) czy spacerów polnymi drogami. Niemal fotograficzny opis rzeczywistości zawiera się często w pojedynczych obrazach, za-

${ }^{23}$ Dosłowne tłumaczenie z japońskiego brzmi Wspomnienia jak spadajace krople deszczu. 
chodzie słońca lub początku dnia, kiedy to rzeczywistość będzie kreowana na nowo. Niby ta sama, a jednak już nieco odmieniona. Japoński twórca, sięgając do tematu pamięci, przywołuje tym samym uczucie nostalgii za minionymi czasami. Ów pierwiastek nostalgiczności doprowadza do konfrontacji tego, co nam się przydarza, z marzeniami, pewną tęsknotą za czymś nieznanym...

Szopy w natarciu (Heisei Tanuki Gassen Ponpoko; Pom Poko) z 1994 roku to kolejna animacja poruszająca sprawę ekologii, robi to jednak w sposób dla twórczości Isao Takahaty niekonwencjonalny. Tanuki, w Polsce zwane jenotami (z wyglądu przypominają szopy), zamieszkują zalesione wzgórze na przedmieściach Tokio. Ich społeczność jest liczna, a sąsiedzkie klany niemal nie prowadzą ze sobą wojen. Gdy dowiadują się, że na ich terenie deweloperzy planują wybudować osiedle mieszkaniowe, postanawiają za wszelką cenę nie dopuścić do jego budowy. Według japońskich przekazów i legend tanuki opanowały do perfekcji sztukę transformacji, są w stanie zmienić się w dowolną rzecz, a te bardziej doświadczone nawet w ludzi. By nie utracić swojego domu, tanuki będą zmuszone wspiąć się na wyżyny swych umiejętności. Warto dowiedzieć się, co sam reżyser mówi o inspiracjach związanych z pracami nad tym filmem:

To temat bliski memu sercu. Opowieści o przemianach tanuki często pojawiają się w japońskiej tradycji, ale uważa się je za głupotę i nikt nie ma odwagi się nimi zająć. Przyznaję, że kiedy pierwszy raz zobaczyłem prawdziwego szopa, byłem rozczarowany - baśnie wydawały mi się znacznie bardziej interesujące. Aby ukazać metamorfozę tanuki w czasach współczesnych, inspirowałem się wszystkimi możliwymi postaciami: prawdziwym zwierzęciem, jego formą pojawiającą się w mangach i wyobrażeniem z drzeworytów ukiyoe - na przykład z mang Sugiury Shigeru i tanuki Kuniyoshiego. Jeśli chodzi o yōkai, „pożyczyłem” postacie ze zwojów o Nocnym pochodzie stu demonów oraz z drzeworytów Hokusaia i Kuniyoshiego ${ }^{24}$.

Szopy w natarciu wskazują nie tylko na problem coraz bardziej widocznej przewagi miasta nad wsią, lecz także na niektóre z poglądów Takahaty. Antropomorfizm, który się tu pojawia, przywodzi na myśl wspomnianą na początku eseju koncepcję, wedle której manga miała swe początki w czasach tworzenia iluminowanych zwojów, na których niezwykle często pojawiały się zwierzęta obdarzone ludzkimi cechami. Zmiennokształtność tanuki oraz przygotowana przez nie z ogromnym rozmachem miejska parada $y \bar{o} k a i^{25}$ to oczywiście elementy fantastyczne, „wkradające się” do logicznego świata japońskiego twórcy. Jest to licentia poetica $\mathrm{w}$ dokonaniach reżysera, na którą mógł sobie pozwolić. Znamienne jest, że za pomysł historii odpowiada także Hayao Miyazaki. Na myśl przychodzi pytanie, czy Takahata jest ostatnim „strażnikiem realnego świata” w Studiu Ghibli?

Początkowo to Miyazaki w 1995 roku eksperymentował z animacją cyfrową, przy okazji On Your Mark, z kolei w cztery lata później Takahata stworzył pierwszy pełnometrażowy film w całości animowany cyfrowo, nosił tytuł Rodzinka Yamadów (Hōhokekyo Tonari no Yamada-kun; My Neighbors the Yamadas, 1999). Zmianę zamysłu artystycznego widać już w pierwszych kadrach. Animacja miała być niczym haiku - nieco żartobliwa, pozostawiająca widza z pewną refleksją. Efekt ten uzyskano m.in. dzięki prostej kresce, rezygnacji z tła oraz braku detali. Oto Nonoko - córka państwa Yamadów, która na wstępie przedstawia

\footnotetext{
24 B. Koyama-Richard, op. cit., s. 233-234.

25 Yōkai to ogólna nazwa wszelkich stworzeń, duchów i demonów występujących w japońskiej mitologii.
} 
widzowi resztę swojej rodziny. W jej skład wchodzi: Takashi - głowa rodziny, „zmęczony mąż wracający do domu po pracy”; Matsuko - pani domu próbująca sprostać tysiącom trudnych zadań, każdego dnia; Noboru - syn Yamadów o spokojnym usposobieniu, czasem marzą mu się nowocześni rodzice; Shige - babcia potrafiąca poradzić sobie nawet z gangiem motocyklowym, oraz pies Pochi. W takim towarzystwie mija im dzień za dniem. Każdy ma swoje, zupełnie inne problemy, trzeba wymyślić co zrobić dzisiaj na obiad, kto będzie dzierżył w dłoni pilota od telewizora, jak umówić się z dziewczyną, by rodzice i siostra się nie dowiedzieli... Reżyser dał się poznać jako wybitnie spostrzegawczy obserwator, z łatwością dostrzegając, tak przecież ulotne, elementy prozy życia.

Dzieła Isao Takahaty dowodzą, że portretowanie codzienności i zwyczajności ludzkiej egzystencji zawiera w sobie ulotną magię, która często znaczy więcej niż nawet najwymyślniejsza fantazja.

\section{Na styku dwóch światów}

Pod szyldem Studia Ghibli powstawały także filmy innych twórców, były to produkcje „gościnne" lub debiuty młodszych animatorów następnego pokolenia tegoż studia.

Historia animacji telewizyjnej pt. Szum morza (Umi ga Kikoeru; Ocean Waves, 1993, reż. Tomomi Mochizuki) rozgrywa się w Kōchi, a jej główną postacią jest Taku wspominający czasy liceum, swojego najlepszego przyjaciela oraz dziewczynę, w której obaj byli zakochani. Mochizuki skupia się głównie na seriach filmowych, a w jego opowieści nie pojawiają się elementy fantastyczne. Bohaterowi towarzyszy jednak nostalgia, zbliżona w pewien sposób do tej z Powrotu do marzeń. Yoshifumi Kondō był jednym z animatorów Studia Ghibli oraz potencjalnym następcą Miyazakiego i Takahaty, był także reżyserem Szeptu serca (Mimi o Sumaseba; Whisper of the Heart) z 1995 roku. Dziewczyna imieniem Shizuku odkrywa, że wszystkie książki, jakie wypożycza z biblioteki, były czytane wcześniej przez jedną i tę samą osobę. Kiedy trafia do pewnego antykwariatu poznaje historię figurki kota o imieniu Baron. Zafascynowana opowieścią, pragnie o niej napisać. Fantastyczne sekwencje, które są wyobrażeniami Shizuku na temat Barona, mają swoje odzwierciedlenie w jeszcze bardziej fantazyjnej Narzeczonej dla kota (Neko no Ongaeshi; The Cat Returns, 2002). Reżyser Hiroyuki Morita jest doświadczonym animatorem, który prócz Studia Ghibli współpracował m.in. z Satoshi Konem. Tytułowa narzeczona Haru zostaje zamieniona w kota i przeniesiona do Kociego Królestwa, gdzie ma poślubić księcia. Baron ruszy jej na ratunek. Z kolei Tajemniczy świat Arrietty (Kari-gurashi no Arietti; The Borrower Arrietty, 2010) to debiut Hiromasy Yonebayashiego - stałego pracownika Studia Ghibli. Pomysł tu wykorzystany zaczerpnięto z powieści Mary Norton o „pożyczalskich”, małych stworzeniach żyjących pod podłogą. To za ich sprawą z domu znikają różne drobiazgi, ale ich życie skomplikuje się, gdy chłopiec Sho odkryje ich istnienie. Najciekawszy przypadek w kontekście badań nad charakterem kreowanych światów stanowi syn Hayao Miyazakiego - Goro. Goro Miyazaki, z jednej strony reżyser Opowieści z Ziemiomorza (Gedo Senki; Tales from Earthsea, 2006) opartych na podstawie jednego z najbardziej rozbudowanych fantastycznych światów (jego twórczynią jest Ursula Kroeber Le Guin), z drugiej twórca Makowego wzgórza (Kokuriko-zaka Kara; From Up on Poppy Hill, 2011) - opowieści o sile pamięci; portretującej powojenną japońską rzeczywistość początku lat 60., kiedy Kraj Wschodzącego Słońca bu- 
dził się na nowo do życia. Czas pokaże, która wizja świata zapanuje w twórczości młodego reżysera.

Być może wcale nie trzeba będzie wybierać? Zetknięcie obu światów staje się coraz bardziej możliwe. Najlepszym tego przykładem jest anime Szopy w natarciu, gdzie świat rzeczywistości i fantazji koegzystują ze sobą. Badając artystyczne dokonania Miyazakiego i Takahaty, można zauważyć, że obaj czerpią z jednego źródła - z japońskiej tradycji. Odmienność wynika z sięgania do różnych jej obszarów. Miyazaki sięga częściej do starożytnych mitów i wierzeń, Takahata zaś skupia się na tradycji życia codziennego. Takahata często upatruje go w wiejskich zakątkach, gdzie życie płynie wolno, z dala od zgiełku wielkich miast. Miyazaki z kolei, ukazuje zagrożenia wynikające z procesu rozwoju cywilizacji (głównie przemysłowego), swoją uwagę szczególnie skupiając na ekologii. Zatem mimo odrębności tematów w twórczości założycieli Studia Ghibli uzupełniają się one, często bywając swoimi ekstensjami. Są pewnego rodzaju przedłużeniami, które wynikając z siebie, wzajemnie współistnieją.

W Studiu Ghibli, dwa światy - fantastyczny i realny - będą miały zapewnione wieczne życie, nawet jeśli nie samodzielnie, to łącząc się z kolejnym, pozornie odmiennym, a w rzeczywistości tak bardzo bliskim. 